Franziska Kobe', Martin K. Bittner ${ }^{1}$, Christian Leipe ${ }^{1,2}$, Philipp Hoelzmann ${ }^{3}$,

1 Institute of Geological Sciences, Paleontology, Freie Universität Berlin, Berlin, Germany

${ }^{2}$ Institute for Space-Earth Environmental Research (ISEE), Nagoya University, Nagoya, Japan

${ }^{3}$ Institute of Geographical Sciences, Physical Geography, Freie Universität Berlin, Berlin, Germany

${ }^{4}$ School of Geographical Sciences, University of Nottingham Ningbo China, Ningbo, China

${ }^{5}$ Eurasia Department and Beijing Branch Office, German Archaeological Institute, Berlin, Germany

*Corresponding author: ptarasov@zedat.fu-berlin.de

\title{
LATEGLACIAL AND EARLY HOLOCENE ENVIRONMENTS AND HUMAN OCCUPATION IN BRANDENBURG, EASTERN GERMANY
}

ABSTRACT. The paper reports on the results of the pollen, plant macrofossil and geochemical analyses and the AMS ${ }^{14} \mathrm{C}$-based chronology of the «Rüdersdorf» outcrop situated east of Berlin in Brandenburg (Germany). The postglacial landscape changed from an open one to generally forested by ca. 14 cal. kyr BP. Woody plants (mainly birch and pine) contributed up to 85\% to the pollen assemblages ca. 13.4-12.5 cal. kyr BP. The subsequent Younger Dryas (YD) interval is characterized by a decrease in arboreal pollen (AP) to $75 \%$ but led neither to substantial deforestation nor spread of tundra vegetation. This supports the concept that the YD cooling was mainly limited to the winter months, while summers remained comparably warm and allowed much broader (than initially believed) spread of cold-tolerant boreal trees. Further support for this theory comes from the fact that the relatively low AP values persisted until ca. 10.6 cal. kyr BP, when the «hazel phase» of the regional vegetation succession began. The postglacial hunter-gatherer occupation is archaeologically confirmed in Brandenburg since ca. 13 cal. kyr BP, i.e. much later than in the western part of Germany and ca. 1000 years after the major amelioration in the Rüdersdorf environmental record.

KEY WORDS: pollen analysis, plant macrofossils, sediment geochemistry, AMS ${ }^{14} \mathrm{C}$ dating, vegetation, climate change

CITATION: Franziska Kobe, Martin K. Bittner, Christian Leipe, Philipp Hoelzmann, Tengwen Long, Mayke Wagner, Romy Zibulski, Pavel E. Tarasov (2019) Lateglacial and early Holocene environments and human occupation in Brandenburg, eastern Germany. Geography, Environment, Sustainability, Vol.12, No 2, p. 132-147

DOI-10.24057/2071-9388-2018-50 


\section{INTRODUCTION}

In the recent decades of globally documented climate warming, concern is growing that it will have widespread impact on the world's environments and human populations (IPCC 2014). However, these future impacts are poorly constrained by ecosystem models and direct observations. Therefore, reconstruction of possible effects of past climatic changes on vegetation, animal and human population dynamics remains one of the key tasks of palaeoenvironmental research. In particular, multidisciplinary studies of ecosystem transformations, which occurred in response to global warming during the Lateglacial-Holocene transition ca. 15-8 thousand calendar years before present (cal. kyr BP) and was of comparable magnitude to climatic change predicted for the next hundred years, are of increasing importance.

The environmental response of European terrestrial and limnic ecosystems to the distinct climatic fluctuations at the end of the last glaciation varied both in time and space, depending on local and regional climatic conditions and on the distance to the Atlantic Ocean and adjacent ice sheets (Wohlfarth et al. 2007). Palaeoenvironmental and palaeoecological reconstructions of the response to these climatic fluctuations remain hampered by problems inherent with ${ }^{14} \mathrm{C}$ dating (de Klerk 2002; Litt et al. 2009) and limited by the availability of high-resolution Lateglacial and early Holocene terrestrial records from many regions. Although new investigations are now emerging from different regions offering the possibility to address these issues in greater detail, there are many areas (even within Europe), where understanding Lateglacial and early Holocene climatic and environmental conditions requires more in-depth studies (Tarasov et al. 2018) in order to be robustly correlated with reference environmental archives across Eurasia (e.g. Namiotko et al. 2015; Stebich et al. 2009, 2015; Schlolaut et al. 2017).

The landscapes of the Federal States Berlin and Brandenburg in eastern Germany are part of the North German plains and low- lands predominantly formed by Weichselian glacial and periglacial processes. The area includes many lakes and peatlands, the deposits of which are important palaeoecological archives. Palynological studies into Lateglacial and early Holocene vegetation history are numerous (e.g. Behre et al. 1996 and references therein), however, would greatly benefit from higher temporal resolution and better chronological control (de Klerk 2002). A misbalance in the dating quality is particularly noticeable when comparing Lateglacial and early Holocene environmental archives from the eastern part of Germany with annually laminated lacustrine sediments from the Eifel maars in the southwestern part (Sirocko 2009).

To contribute in filling this gap, we performed a multi-proxy palaeoenvironmental study of a Lateglacial to early Holocene sedimentary section from Rüdersdorf near Berlin (Fig. 1a, b). The area is best known for its unique Triassic limestone deposits, which represents the largest geological outcrop of the Mesozoic in northern Germany (Schroeder 2015). The limestone exploitation in the Rüdersdorf quarry (Fig. 1c) requires removal of relatively thin Weichselian glacial and postglacial sediments covering the Triassic layers. These works allow rescue of well-preserved sections composed of Lateglacial-early Holocene limnic-telmatic sediments (Fig. 1d). The outcrop "Paddenluch" (Fig. 1c) has been intensively studied for faunal and macrobotanical remains and ${ }^{14} \mathrm{C}$-dated using $\mathrm{Ac}$ celerator Mass Spectrometry (AMS) to the Lateglacial and Holocene intervals (Kossler 2010). Our current study reports results of the pollen, plant macrofossil and geochemical analyses and the AMS ${ }^{14} \mathrm{C}$ dating of the "Rüdersdorf" outcrop situated ca. 650 $\mathrm{m}$ west of the Paddenluch (Fig. 1c). In the accompanying discussion we address the following issues: (i) the local and regional environments during the Younger Dryas (YD) interval (ca. 12.7-11.6 cal. kyr BP); (ii) the onset of the "hazel phase" in the vegetation development; and (iii) the postglacial environments and hunter-gatherer occupation. 

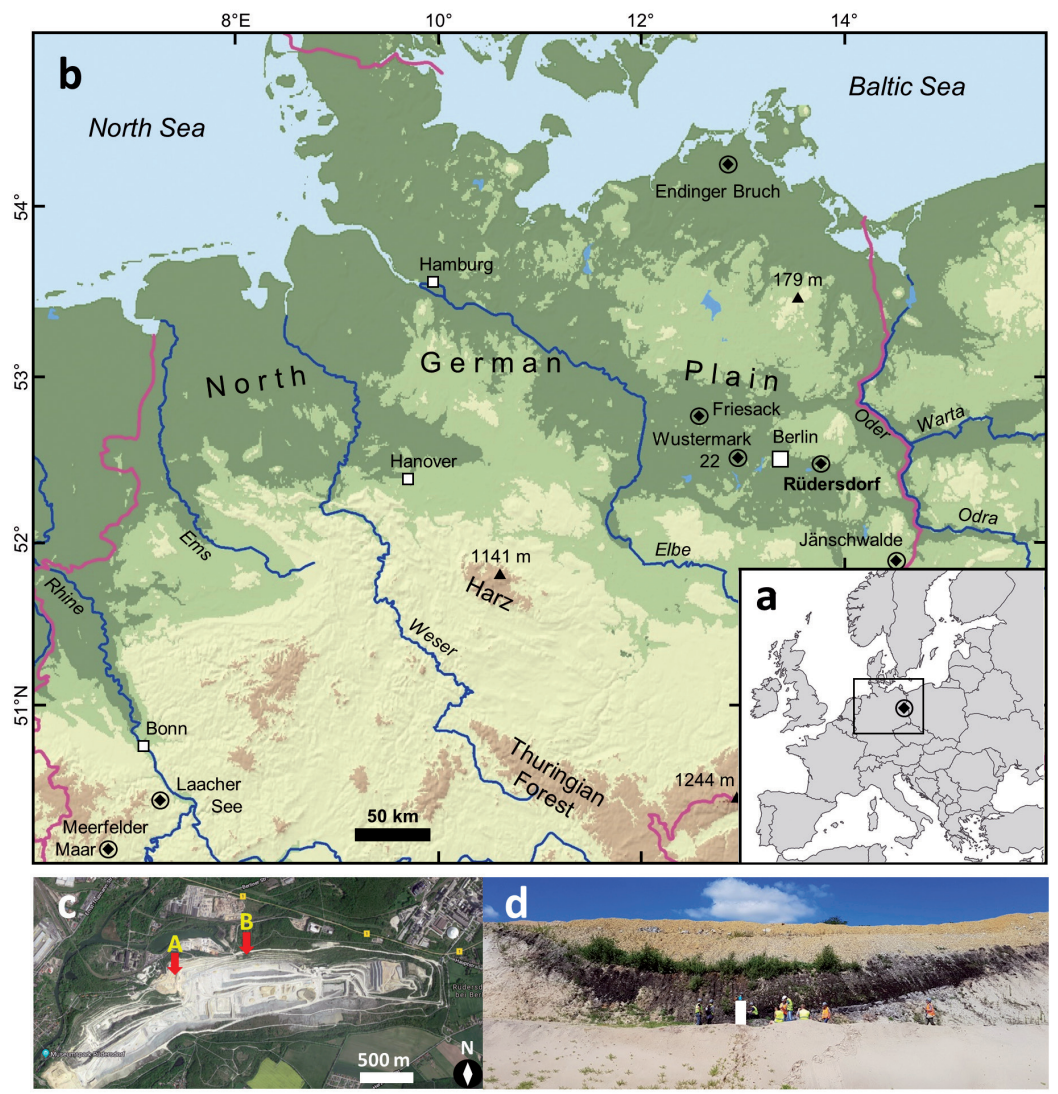

Fig. 1. a) Location of the Rüdersdorf site in central Europe; b) topographic map of northern Germany indicating positions of the key sites discussed in the text; c) aerial image of the Rüdersdorf limestone quarry and locations of the Rüdersdorf (arrow A) and Paddenluch (arrow B) outcrops; d) photo of the Rüdersdorf outcrop and the sampled section (white column) representing the Lateglacial-early Holocene interval

\section{SITE SETTING AND REGIONAL ENVIRONMENTS}

The study site $\left(52^{\circ} 29^{\prime} \mathrm{N}, 13^{\circ} 48^{\prime} \mathrm{E}\right.$, ca. $30 \mathrm{~m}$ a.s.l.) is located in the northern part of the active limestone quarry in Rüdersdorf operated by the CEMEX OstZement GmbH Werk Rüdersdorf. The quarry is situated approximately $30 \mathrm{~km}$ southeast of Berlin on the ground moraine of the Barnim Plateau, just north of the Warsaw-Berlin glacial valley (Schroeder 2015). The major Weichselian ice extent in the study area occurred during the Brandenburg Phase prior to ca. 21 cal. kyr BP (Hardt and Böse 2018). The retreat and melting of the glaciers left sandy soils and a complex system of rivers and lakes. The end moraines of the Frankfurt Stage are documented north of Rüdersdorf suggesting that the area was already free of permanent ice after ca. 18.4 cal. kyr BP (Schroeder 2015). Although exact dates are still under debates (e.g. Hardt and Böse 2018), the AMS-dated remains of Armeria maritima (sea thrift) from the Paddenluch outcrop show that the area was undoubtedly ice-free (including dead ice in kettle holes) and vegetated by ca. 15 cal. kyr BP (Kossler 2010). The Rüdersdorf outcrop analyzed here likely represents one of the shallow water lakes that appeared in topographic depressions on the fluvio-glacial surface of the Barnim Plateau at about the same time.

The modern climate of the area is sub-continental within an oceanic-continental transitional zone (Behre et al. 1996). It is characterized by a mean January temperature of $-0.7^{\circ} \mathrm{C}$, a mean July temperature of 
$18^{\circ} \mathrm{C}$, and an annual precipitation of about $580 \mathrm{~mm}$ (ca. $65 \%$ of this sum falls during the vegetative period). The study area is situated within the temperate deciduous forest biome zone, although located very close to the western margin of the cool mixed forest zone (Prentice et al. 1996). Therefore, vegetation cover of the Barnim region consists of diverse temperate deciduous and cool mixed forest taxa, with Pinus sylvestris (Scots pine), Fagus sylvatica (beech) and Quercus spp. (oak) being dominant.

\section{MATERIALS AND METHODS}

The Rüdersdorf outcrop (Fig. 1d) was sampled on Sunday April 9, 2017. The limited amount of time allowed for sampling in this area of the quarry to which access is usually prohibited, the steep slope of the outcrop and groundwater outflow complicated the fieldwork. The samples (each consisting of 4-cm-thick sediment sequences) were continuously taken from the lower $156 \mathrm{~cm}$ of the cleaned sedimentary section (Fig. 2a), packed in plastic bags and stored in the refrigerator. The sampled section consists of a minerogenic lower part with fine sand $(156-132 \mathrm{~cm})$ and an upper part with partly laminated calcareous gyttja, silt and clay (132-124 cm), organic gyttja (124-103 $\mathrm{cm})$, peaty gyttja $(101-66 \mathrm{~cm})$ and black peat (above $66 \mathrm{~cm}$ ). The interval between 101 and $103 \mathrm{~cm}$ contains a 1-2 cm thick yellowish sediment layer, the Laacher See Tephra (LST) that has been also identified in the Paddenluch section (Kossler 2010). This ash is named after a caldera lake in the Eifel region in western Germany (Fig. 1b), about 500 km southwest of Rüdersdorf. The last eruption of the Laacher See Volcano has been securely dated to $12,937 \pm 23$ cal. yr BP (Bronk Ramsey et al. 2015) and the LST is an important chronological marker of supra-regional importance. Visible plant macrofossils (i.e. small twigs) were also hand-picked from the cleaned surface of the section for AMS dating.

The eight AMS ${ }^{14} \mathrm{C}$ dates on short-lived terrestrial plant macrofossils were generated in the Poznan Radiocarbon Laboratory and used together with the known age of the LST to construct a robust age model for the analyzed sediment sequence. All obtained ${ }^{14} \mathrm{C}$ dates (Table 1) were converted into calendar ages using the OxCal v.4.3.2 software package (Bronk Ramsey 1995) and the IntCal13 calibration curve (Reimer et al. 2013). We adopted a Poisson process Bayesian depositional model (Bronk Ramsey 2008) to investigate the sequence's age-depth relationship using information from these ${ }^{14} \mathrm{C}$ dates, the known age of LST layer, the key lithological boundaries (LBS) and the estimated minimum age (ca. 11,500 cal. yr BP) for the Lateglacial-Holocene transition (ca. $74 \mathrm{~cm}$ ) based on pollen and geochemistry data (Fig. 2). The OxCal command Boundary() was used to model the selected LBs. The critical values for the agreement index and convergence index in the model were set to, respectively, 60\% and 95\% (Bronk Ramsey 1995). The reconstructed curve was further smoothed by a quadratic regression between the two variables (i.e. modelled calibrated age and depth), in order to minimise influences by individual ${ }^{14} \mathrm{C}$ dating anomalies and to focus on the overall rate of deposition.

A multi-disciplinary approach, including palynological, geochemical and plant macrofossil analyses, was applied to the sediment samples in order to reconstruct local to regional environmental dynamics.

Basic geochemical parameters such as elemental analysis of TIC (total inorganic carbon), TOC (total organic carbon) and TN (total nitrogen) as well as determination of major elements (Fig. 3) by ICP-OES (inductively coupled plasma optical emission spectrometer) on the base of an aqua regia extraction (DIN EN 2001) were conducted for all collected samples. The main mineralogic components were determined by XRD (X-ray diffraction). The XRD-results (Fig. $3)$ are expressed in counts per second (cps), which reflects semi-quantitatively the proportion of the minerals. These common analyses are described in detail in Vogel et al. (2016).

Extraction of pollen, fern spores and other non-pollen palynomorphs (NPPs) was performed according to the protocol described in Leipe et al. (2018). The protocol 
(a) Lithology column

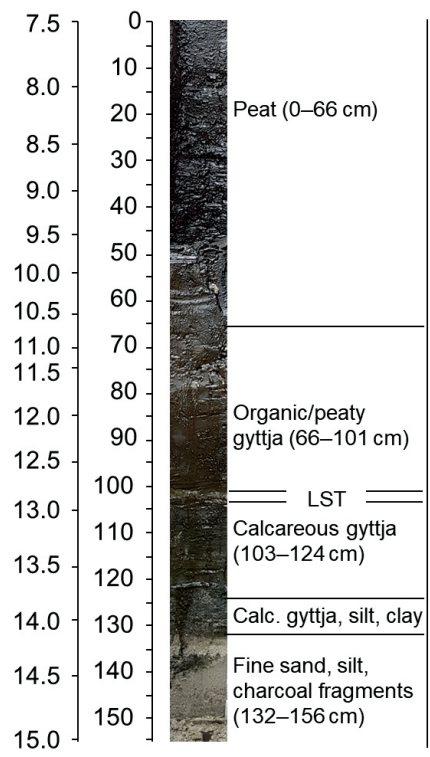

(b) Age-depth relationship

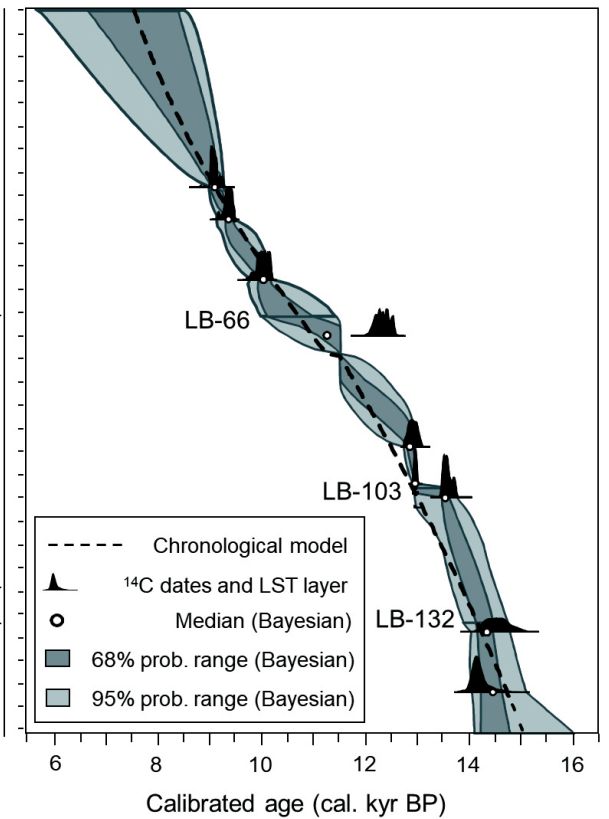

Fig. 2. a) Lithology column and b) age-depth model of the Rüdersdorf section based on the ${ }^{14} \mathrm{C}$ dates (Table 1) and key lithological boundaries (LBs)

Table $1 .{ }^{14} \mathrm{C}$ dates and calibrated ages for the Rüdersdorf section

\begin{tabular}{|c|c|c|c|c|}
\hline $\begin{array}{l}\text { Sample Nr./ } \\
\text { Lab. Nr. }\end{array}$ & $\begin{array}{l}\text { Dated } \\
\text { material }\end{array}$ & $\begin{array}{l}\text { Composite } \\
\text { depth, cm }\end{array}$ & $\begin{array}{l}{ }^{14} \mathrm{C} \text { Date, } \\
\text { uncal. yr BP }\end{array}$ & $\begin{array}{l}\text { Calibrated age (unmodelled), } \\
\text { cal. yr BP (OxCal v.4.3.2) }\end{array}$ \\
\hline $\begin{array}{c}\text { RU-I-9/ } \\
\text { Poz-91180 }\end{array}$ & $\begin{array}{l}\text { twig } \\
\text { fragment }\end{array}$ & 147 & $12240 \pm 70 \mathrm{BP}$ & $\begin{array}{c}\text { 68.2\% probability } \\
\text { 14257BP (68.2\%) 14025BP } \\
\text { 95.4\% probability } \\
\text { 14563BP }(95.4 \%) \text { 13927BP }\end{array}$ \\
\hline $\begin{array}{l}\text { RU-I-20-24/ } \\
\text { Poz-96975 }\end{array}$ & $\begin{array}{l}\text { twig } \\
\text { fragment }\end{array}$ & 134 & $12420 \pm 70 \mathrm{BP}$ & $\begin{array}{c}\text { 68.2\% probability } \\
\text { 14711BP }(68.2 \%) 14279 B P \\
\text { 95.4\% probability } \\
\text { 14948BP }(95.4 \%) 14162 B P\end{array}$ \\
\hline $\begin{array}{l}\text { RU-I-51/ } \\
\text { Poz-91181 }\end{array}$ & $\begin{array}{l}\text { twig } \\
\text { fragment }\end{array}$ & 105 & $11740 \pm 60 \mathrm{BP}$ & $\begin{array}{c}\text { 68.2\% probability } \\
\text { 13696BP (2.2\%) 13685BP } \\
\text { 13610BP (66.0\%) 13465BP } \\
\text { 95.4\% probability } \\
\text { 13725BP }(95.4 \%) 13452 \mathrm{BP}\end{array}$ \\
\hline $\begin{array}{l}\text { Laacher See } \\
\text { Tephra (LST) }\end{array}$ & tephra & 101-103 & - & $\begin{array}{c}12937 \pm 23 \text { cal. yr BP (after Bronk } \\
\text { Ramsey et al., 2015) }\end{array}$ \\
\hline
\end{tabular}




\begin{tabular}{|c|c|c|c|c|}
\hline $\begin{array}{l}\text { RU-I-60-64/ } \\
\text { Poz-96669 }\end{array}$ & $\begin{array}{c}\text { twig } \\
\text { fragment }\end{array}$ & 94 & $11030 \pm 60 \mathrm{BP}$ & $\begin{array}{c}\text { 68.2\% probability } \\
\text { 12984BP (68.2\%) 12811BP } \\
\text { 95.4\% probability } \\
\text { 13044BP (95.4\%) 12744BP }\end{array}$ \\
\hline $\begin{array}{l}\text { RU-I-84-88/ } \\
\text { Poz-96976 }\end{array}$ & $\begin{array}{c}\text { twig } \\
\text { fragment }\end{array}$ & 70 & $10430 \pm 60 \mathrm{BP}$ & $\begin{array}{c}\text { 68.2\% probability } \\
\text { 12518BP (6.5\%) 12488BP } \\
\text { 12425BP (16.0\%) 12366BP } \\
\text { 12358BP }(33.6 \%) 12227 \mathrm{BP} \\
\text { 12213BP }(12.2 \%) 12160 \mathrm{BP} \\
\text { 95.4\% probability } \\
12541 \mathrm{BP}(95.4 \%) 12089 \mathrm{BP}\end{array}$ \\
\hline $\begin{array}{c}\text { RU-II-6/ } \\
\text { Poz-91182 }\end{array}$ & $\begin{array}{c}\text { twig } \\
\text { fragment }\end{array}$ & 58 & $8890 \pm 50$ BP & $\begin{array}{c}\text { 68.2\% probability } \\
\text { 10156BP (13.9\%) 10114BP } \\
\text { 10088BP (54.3\%) 9921BP } \\
\text { 95.4\% probability } \\
\text { 10191BP (88.7\%) 9883BP } \\
\text { 9878BP ( } 1.4 \%) 9861 \mathrm{BP} \\
\text { 9849BP ( 5.3\%) 9785BP }\end{array}$ \\
\hline $\begin{array}{l}\text { RU-II-19/ } \\
\text { Poz-91183 }\end{array}$ & $\begin{array}{c}\text { twig } \\
\text { fragment }\end{array}$ & 45 & $8330 \pm 50 B P$ & $\begin{array}{l}\text { 68.2\% probability } \\
\text { 9430BP (68.2\%) 9295BP } \\
\text { 95.4\% probability } \\
\text { 9473BP (90.4\%) 9237BP } \\
\text { 9222BP ( } 1.3 \%) 9205 B P \\
\text { 9176BP ( } 3.7 \%) 9142 B P\end{array}$ \\
\hline $\begin{array}{c}\text { RU-II-24-28/ } \\
\text { Poz-91186 }\end{array}$ & $\begin{array}{l}\text { twig } \\
\text { fragment }\end{array}$ & 38 & $8130 \pm 50 B P$ & $\begin{array}{l}\text { 68.2\% probability } \\
\text { 9122BP (68.2\%) 9009BP } \\
\text { 95.4\% probability } \\
\text { 9255BP (95.4\%) 8992BP }\end{array}$ \\
\hline
\end{tabular}

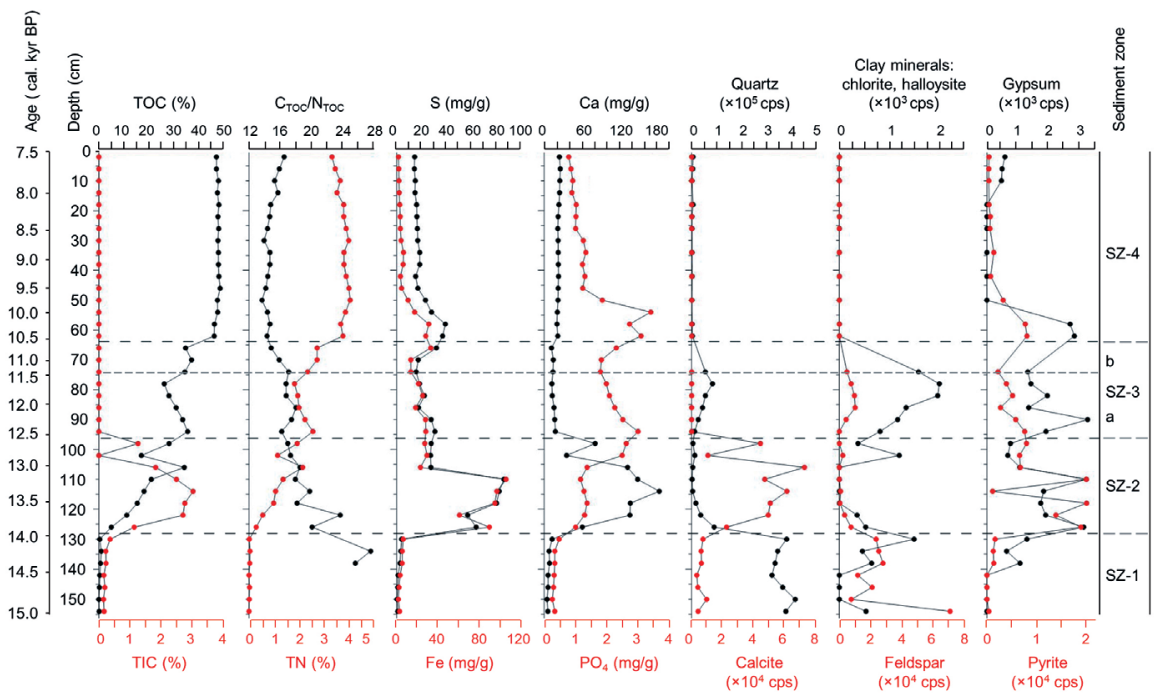

Fig. 3. Rüdersdorf sediment geochemistry for the main components discussed in the text. The XRD-results are expressed in counts per second (cps) 
includes treatment of 0.5 gram of sediment with $10 \% \mathrm{HCl}, 10 \% \mathrm{KOH}$, dense media separation using sodium polytungstate (SPT) at a density of 2.1, and acetolysis. Dense media separation using non-toxic SPT serves for isolating the pollen fraction from siliceous and other heavier sediment particles and is particularly recommended instead of extremely dangerous HF treatment often utilized by palynologists to digest siliceous matter. In order to estimate pollen concentrations, we added a known quantity of exotic Lycopodium clavatum marker spores to each sample prior to lab preparation following Stockmarr (1971). Pollen and NPPs were counted using a light microscope with magnification $\times 400-600$ and taxonomically identified with the help of regional pollen atlases (Beug 2004; Demske et al. 2013 and references therein) and the institute's reference collection. For all analyzed fossil pollen samples, calculated pollen percentages refer to the sum of terrestrial pollen grains. Other counted taxa percentages, including pollen of aquatic plants, spores of ferns and algae remains were calculated using the total terrestrial pollen sum plus the sum of palynomorphs in the respective group. Tilia version 1.7.16 software (Grimm 2011) was used for calculating pollen and NPP taxa percentages and drawing the diagrams.

Plant macrofossils (i.e. remains of plants that are visible by naked eye with a median size of 0.5 to $2 \mathrm{~mm}$ ) were selected and used for AMS ${ }^{14} \mathrm{C}$ dating and for palaeoecological interpretations. Sediment samples were treated with $10 \% \mathrm{H}_{2} \mathrm{O}_{2}$ over night and then washed through a $125 \mu \mathrm{m}$ sieve. Plant macrofossils were picked from the residue using a binocular microscope. Identification was performed using published literature (van Geel 1978; Kossler 2010 and references therein) and a reference collection at the Alfred Wegener Institute for Polar and Marine Research (Potsdam). Specimens were photographed using a Keyence VHX-1000 digital microscope and a ZEISS SUPRATM 40 VP Ultra Scanning Electron Microscope (SEM). To examine oospores of Characeae at the SEM, specimens were dehydrated in a graded ethanol series (10\%, 30\%, 50\%, 70\%, $100 \%)$, dried on a metal stage and coated.

\section{RESULTS AND INTERPRETATONS}

\section{Age-depth model}

The age-depth model for the analyzed Rüdersdorf section (Fig. 2a) is presented in Fig. 2b. In general, estimated ages for the uppermost peat section $(66-0 \mathrm{~cm})$ and lowermost sand/silt section (156-132 $\mathrm{cm}$ ) fit well with the determined ${ }^{14} \mathrm{C}$ dates. There seems to be, however, a certain level of mismatch between ${ }^{14} \mathrm{C}$ dates within the gyttja section $(132-66 \mathrm{~cm})$ and the adopted model. Fortunately, the LST layer provides a unique control point to determine the mismatch. It turns out that the ${ }^{14} \mathrm{C}$ dates in the section are probably older than their depositional contexts. Anomalies are not rare in ${ }^{14} \mathrm{C}$ dating (Long et al. 2016) and one in twenty radiocarbon dates can be expected to be either younger or older than its age of deposition (Bronk Ramsey 2009). In any case, introducing quadratic regression to focus on the overall rate of deposition helped establishing a model in which the influence of single anomalous datings is minimized.

\section{Sediment geochemistry}

The sediment geochemistry (Fig. 3) reveals four sediment units/zones that are mainly reflected by changes in the contents of the organic substance (TOC), calcite (TIC, Ca concentration), iron and sulfur (Fe, S) as well as in varying mineralogical components (mainly quartz, calcite, pyrite, and gypsum).

SZ-1 (156-128 cm, ca. 15,030-13,970 cal. yr BP) reflects almost organic-free pure siliclasts (quartz, feldspars, and partly clay minerals) that represent the Lateglacial sands and silts deposited at a time when the water table had not yet inundated the Rüdersdorf topographical depression. High $\mathrm{C} / \mathrm{N}$ values (up to 28 ) also point to low input of mainly terrestrial organic matter.

SZ-2 (128-96 cm, ca. 13,970-12,560 cal. yr $\mathrm{BP}$ ) is characterized by increasing TOC (up to $34,4 \%$ ), calcite (up to $24 \%$ ) and lowered quartz and feldspar proportions but peaking $\mathrm{Fe}$ and $\mathrm{S}$ contents due to the appear- 
ance of pyrite. The rising groundwater table reached the depression and a lake formed, as shown by the production of organic substance. As the C/N value decreases towards the top, an increase in water plants and algae contribute to the organic substance produced in the lake. The relatively high gypsum peaks in the XRD-diagrams reflect the local geology including gypsum deposits. The parallel trend of Fe and $S$ throughout the entire section points out that pyrite formed authigenically. Calcite probably formed during summer when temperature and biological production were highest.

SZ-3 (96-64 cm, ca. 12,560-10,570 cal. yr $\mathrm{BP}$ ) is characterized by high TOC (26.3 to $37.3 \%)$ and phosphate contents, but missing presence of calcite. Probably the organic production increased with lowered water depth and the high organic content dissolved formerly present calcite in the sediments (Dean 1999). The increased quartz and clay mineral (chlorite and halloysite) contents point to an increased aeolian detrital input from the catchment. This sediment zone represents a shallowing lake that steadily transforms into a lowland fen/moor.
At SZ-4 (64-0 cm, ca. 10,570-7540 cal. yr $\mathrm{BP})$ the Rüdersdorf depression reached a state when peat was formed as shown by TOC contents between 46.4-48.8\%, that would represent organic substance well above $80 \%$. Minerogenic components are almost absent and also gypsum shows only low contents reflecting low input of groundwater. However, the $\mathrm{C} / \mathrm{N}$ ratios around 14 represent a mixture between organic matter produced by subhydric algae and terrestrial plants - typical for a lowland fen/moor.

\section{Micro- and macrofossil remains}

Results of the palynological investigation are shown in a simplified pollen diagram (Fig. 4). Five local pollen zones (LPZ) objectively defined with the help of CONISS represent most important changes in the pollen assemblages and in regional and local environments between ca. 15 and 8 cal. kyr BP.

The lowermost LPZ-1 (156-128 cm, ca. 15,030-13,970 cal. yr BP) reveals very low pollen concentration suggesting quick sedimentation and/or sparse vegetation cover. Arboreal pollen (AP) taxa percentages are low indicating a generally open landscape. The most distinctive taxa are

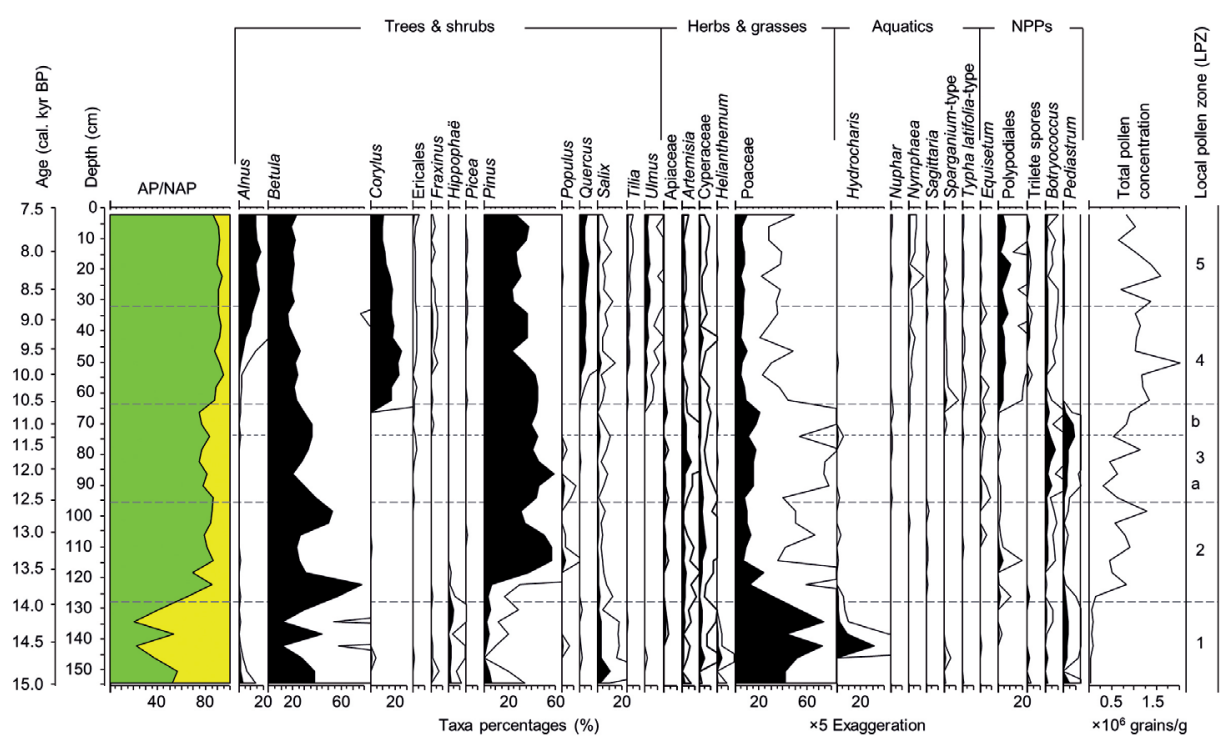

Fig. 4. Percentage diagram showing simplified results of the palynological analysis of the Rüdersdorf section 
Betula, Salix and Hippophäe, suggesting that riparian tree and shrub communities with birches, willows and sea buckthorn grew close to the site. Low percentages of Pinus likely represent air transport from more distant region to the south. Among the non-arboreal pollen (NAP) taxa, Poaceae, likely representing coastal grass vegetation, absolutely predominates. Hydrocharis (frogbit) and Pediastrum green algae colonies represent relatively shallow and quiet aquatic environments. Identifiable plant macrofossils were not found in this zone but twig fragments collected from 147 and $134 \mathrm{~cm}$ (Table 1) likely represent willow or sea buckthorns growing near the site.

LPZ-2 (128-96 cm, ca. 13,970-12,560 cal. yr BP) is characterized by a noticeable increase in pollen concentrations and high AP contents (up to 85\%) indicating a dense vegetation cover and high proportions of woody plants in the study area. Pines and birches are major pollen contributors. The NAP taxa composition is relatively rich representing meadow vegetation. Virtual disappearance of Hydrocharis pollen and higher proportions of fern spores likely indicate a shallow lake or pond. The macrofossil assemblage from 128-124 cm (ca. 13,970-13,800 cal. yr BP) reveals remains of Gasterosteus aculeatus (three-spined stickleback). This small fish prefers slow-flowing water bodies (fresh, brackish or saline) with areas of emerging vegetation. Hippuris vulgaris (mare's tail) fruits also suggest submerged or littoral growth in carbonate-rich stagnant or slow-flowing water and summer temperatures above $13^{\circ} \mathrm{C}$. Poorly preserved Betula sp. seeds indicate presence of birches in the local vegetation. Daphnia pulex (the most common species of water flea) ephippia remains stand for a winter or dry-season resting stage and may indicate stress associated with the Lateglacial climate and small-pool environments.

LPZ-3 (96-64 cm, ca. 12,560-10,570 cal. yr $\mathrm{BP})$ reveals a small-scale decrease in the pollen concentrations and AP values (to 75\%), which coincides with a relative increase in Poaceae and Artemisia percentages, suggesting a decrease in the regional tree cover and local spread of grass and wormwood communities, which may indicate climate deterioration and seasonally drier environments, particularly obvious in the lower part of this zone, prior to ca. 11,650 cal. yr BP. The sediment from 68-64 cm (ca. 10,830-10,570 cal. yr BP) reveals fruits of Groenlandia densa (opposite-leaved pondweed). It occurs in flowing and stagnant waters, but prefers warm summer conditions, in agreement with the early Holocene dates. Betula seeds were also found in the sediment.

LPZ-4 (64-32 cm, ca. 10,570-8790 cal. yr BP) demonstrates a return to very high pollen concentrations and AP percentages reaching 95\%. Corylus (hazel) dominates this zone together with Pinus and Betula suggesting that regional climate became significantly warmer. Appearance of Quercus, Ulmus, Tilia, Alnus and some other temperate deciduous taxa supports this interpretation and indicates the development of species-rich temperate deciduous forests with oak, elm, lime and alder trees and abundant hazel shrubs in the understory layer. Noticeable increase in Polypodiaceae spores in this zone suggests development of a fern cover and mire environments. The macrofossil assemblage from 52-48 cm (ca. 9850-9600 cal. yr BP) reveals remains of submerged plants, e.g. Nymphaea alba (white water lily) and Ceratophyllum demersum (rigid hornwort) preferring slowly flowing to stagnant warm and eutrophic waters, and littoral community members, e.g. Carex pseudocyperus (cyperus sedge) and Scirpus lacustris (lakeshore bulrush). This suggests that the site was flooded, at least seasonally or periodically. On the other hand, needles and bark of Pinus sylvestris and catkins of Betula pendula and B. pubescens indicate the presence of tree birch and pine in the near vicinity during the entire telmatic phase.

LPZ-5 (32-0 cm, ca. 8790-7540 cal. yr BP) differs from the previous LPZ-4 by higher proportions of temperate deciduous trees and a moderate decrease in hazel percentages. This change may indicate the development of canopy trees leading to a relatively sparsely vegetated understory. Abundant fern spores indicate local 
mire environments. On the other hand, the presence (even in low quantities) of pollen of aquatic plants may indicate proximity of the sampled site to a shallow water body.

\section{DISCUSSION}

\section{The Younger Dryas landscape at Rüdersdorf}

The YD palynozone in Germany is dated to ca. 12,680-11,590 cal. yr BP based on varve counting in the sediment cores from the Eifel maar lakes (Litt et al. 2007). As the most recent and longest of several interruptions of the gradual warming of the Earth's climate since the end of the Last Glacial Maximum, the YD signifies a last return to glacial conditions before the onset of the Holocene. The YD cold oscillation is named after the indicator alpine-tundra herbaceous plant Dryas octopetala (white dryad), as its leaves were typically found in the Lateglacial sediments of Denmark and southern Sweden. Due to the scarcity of annually laminated lake sediments precise allocation (and dating) of the YD in the lacustrine sequences across the world proved to be a non-easy task (e.g. Stebich et al. 2009; Tarasov et al. 2018 and references therein). The long-year discussion of presence/absence of woods in different parts of Europe during the YD and the role of woody plants in the Lateglacial vegetation cover cannot be adequately resolved without secure chronological control. In eastern Germany, the reference pollen record from Tegeler See (Berlin), for example, has been reported as representing the entire Lateglacial-Holocene interval (Behre et al. 1996). However, this assumption is based on three conventional ${ }^{14} \mathrm{C}$ age determinations, with the oldest dating within the Boreal phase of the Holocene. Noticeably for the Lateglacial chronology issue, of the $12{ }^{14} \mathrm{C}$ dates from the five palynologically investigated sections in the Endinger Bruch, northeastern Germany, 10 revealed either too young or too old ages (de Klerk 2002).

Kossler (2010) reported a series of 10 AMS ${ }^{14} \mathrm{C}$ age determinations based on seeds and leaves of terrestrial plants from the Paddenluch and reliably established the chrono- logical frame of the YD in the analyzed section. The macrofossil analysis of the YD sediments in the Paddenluch provided results, which do not support a treeless character of the surrounding landscape. The presence of tree birches (Betula pubescens and B. pendula), Scots pine, aspen (Populus tremula) and willow remains, on the one hand, and the absence of the characteristic tundra elements in the macrofossil record, on the other hand, disagree with the reconstruction of tundra or a park-tundra landscape in Brandenburg during the YD (see Kossler 2010, for discussion and references). The pollen record from the Rüdersdorf section presented here corroborates the plant macrofossil record, suggesting that pine and birch woods were rather common in the Brandenburg area during the YD. This, in turn, indicates rather warm summer temperatures in mid-latitude Central Europe and supports climate model simulations suggesting mean July temperatures in the study region as high as $15-16^{\circ} \mathrm{C}$ during the YD (Renssen and Isarin 1997 ; Schenk et al. 2018). The results from Rüdersdorf and from other areas across northern Eurasia (e.g. Stebich et al. 2009; Werner et al. 2010) demonstrate that the pronounced YD cooling was mainly limited to the winter months, while summers remained comparably warm, thus promoting growth and much broader (than initially believed) spread of cold-tolerant boreal summergreen and eurythermic conifer tree and shrub taxa (Kossler 2010; Werner et al. 2010).

\section{The onset of the "hazel phase" in the records from western and eastern Germany}

Corylus avellana (common hazel) is a species of hazel native to Europe and characteristic for the cool temperate deciduous tree/shrub plant functional type, contributing to a number of forest biomes in the temperate climate zone. Wind-pollinated hazel is one of the great pollen producers; therefore, Corylus is a common constituent of European pollen diagrams. In the pollen records from Germany it shows a well-recognized maximum during the early Holocene (e.g. Behre et al. 1996). However, an 
asynchronous onset of the Corylus phase in the southern (southwestern) and northern (northeastern) parts of Germany has been presented (Sirocko 2009) suggesting substantial differences in climatic/environmental conditions and in availability of this important economic plant for Mesolithic hunter-gatherers. In the most accurately dated pollen records from Holzmaar and Meerfelder Maar (Fig. 1b) in the Eifel region (Litt et al. 2009) the Corylus percentages grow from a few to almost $80 \%$ of the total pollen sum between ca. 11,000 and 10,500 varve yr BP and maximal values persist until ca. 9000 varve yr BP. In the Rüdersdorf pollen record, the maximum values are much lower (i.e. 25\%) and similar to other pollen records from Brandenburg, i.e. 30\% in the Tegeler See diagram (Behre et al. 1996). As approved by the AMS dates from the Rüdersdorf section, the maximum values of Corylus pollen occurred ca. 9800-9300 cal. yr BP, i.e. much later than in the Eifel. However, the first rapid increase in Corylus pollen percentages up to $15 \%$ in the Rüdersdorf section dates to around 10,500 cal. yr BP. Bearing this in mind, the early Holocene pattern of hazel spread in the two regions becomes much more similar.

\section{Postglacial environments and hunter-gatherer occupation of Brandenburg}

The retreat of the Weichselian ice sheet and the development of a sparse vegetation cover in the Rüdersdorf area by ca. 15 cal. kyr BP have been proved with the help of palaeobotanical data and AMS ${ }^{14} \mathrm{C}$ dating (Kossler 2010). Since then, the area, rich in lakes, ponds and rivers, was a potential summer grazing ground for herds of migrating herbivores (i.e. reindeers and horses) and numerous water birds. Thus, it would have been also attractive for the hunter-gatherers of that time, at least during the summer months. However, presence of Late Paleolithic people in Brandenburg has been archaeologically proved only since ca. 13 cal. kyr BP (Bönisch 2014), i.e. much later than in the western part of Germany (Sirocko 2009) and ca. 1000 years after the major amelioration in the Rüdersdorf environmental record. Investigations reported by Oppenheimer (2011) suggest that the initial eruption of the Laacher See Volcano took place in late spring or early summer, but volcanic activity continued for several weeks or months leaving near the crater over 50-m-thick tephra deposits exterminating all plants and animals within a distance of ca. $60 \mathrm{~km}$ to the northeast and ca. $40 \mathrm{~km}$ to the southeast. Tephra deposits from the eruption dammed the Rhine, creating a lake ca. $140 \mathrm{~km}^{2}$ in areal extent (Schmincke et al. 1999). Riede (2008) suggested that the eruption also had a dramatic impact on forager demography all along the northern periphery of the Lateglacial settlement area and precipitated archaeologically visible cultural change. The area most affected by the fallout, the Thuringian Basin, appears to have been largely depopulated, whereas populations in southwest Germany and France increased. Whether the hunter-gatherer population movement to the area of northeastern Germany was (at least partly) stimulated by the catastrophic explosion of the Laacher See Volcano remains an interesting topic for future studies.

The first traces of postglacial hunter-gatherers in Brandenburg fall within the Allerød interstadial (13,350-12,680 varve yr BP; Litt et al. 2007) and postdates the onset of the Lateglacial warming during the Meiendorf interstadial (14,450-13,800 varve yr BP; Litt et al. 2007). The environmental situation during the second part of the Lateglacial must have been not much different from that of the end of the penultimate Saale glaciation, about 130 kyr BP, which the oldest Neanderthal stone tools recently discovered in Jänschwalde, Brandenburg (Fig. 1b), have been assigned to (Bönisch 2014). Animal bones and plant remains associated with the finds show that at that time (i.e. ca. 2 kyr before the onset of the penultimate Eemian interglacial) there was a water-rich valley covered by open boreal forest vegetation inhabited by large mammals such as wolf, horse, elk and bison (Bönisch 2014). The Late Paleolithic people living in Brandenburg by the end of the Lateglacial could also rely on a rich fauna, as revealed by the abundant fossil vertebrate remains from the archaeological site Wustermark 
22 (Fig. 1b) west of Berlin (Gramsch et al. 2013). The list of identified species dated to ca. 13.6-11.5 cal. kyr BP includes elk and reindeer (abundant bone remains), but also wild horse, roe deer, aurochs, beaver, brown bear, wolf and wild boar. However, bones of pike are the most numerous indicating that fish was also an important component of the human diet (Gramsch et al. 2013). A further evidence of fishing as a part of the subsistence strategy of the Late Paleolithic groups comes from the fishhooks made of bone material found in the YD layers of Wustermark 22 (Gramsch et al. 2013). Pike, which is also present in the macrofossil assemblage of the Paddenluch dated to ca. 14-13 cal. kyr BP (Kossler 2010), has been the most frequent fish species in the Late Paleolithic to Early and Late Mesolithic archaeological sites in northern Central Europe (Cziesla 2004).

Early to Late Mesolithic hunter-gatherer occupation in Brandenburg was reconstructed in detail by excavating the multilayered site Friesack 4 northwest of Berlin (Fig. 1b). During the entire period from ca. 11 to 7.8 cal. kyr BP hunter-gatherers repeatedly visited this lake shore site, as documented by approximately 100 archaeological layers, about 140,000 Mesolithic and 18,000 Neolithic stone artifacts, thousands of animal bones and plant remains (Gehlen 2009). Bone and antler artifacts, the remains of Mesolithic fishing nets and abundant shells of hazelnut indicate a very broad subsistence strategy, including hunting of a great number of forest and water animals, birds and turtles, but also fishing and collecting edible nuts and berries during the early Holocene (Gramsch 2000).

\section{CONCLUSIONS}

The results of the multi-proxy study of the limnic-telmatic sedimentary section from Rüdersdorf near Berlin presented in the current study allow the following conclusions. The postglacial landscape in the study area changed from predominantly open and sparsely vegetated to generally forested by about 14 cal. kyr BP, as suggested by a high proportion of AP (mainly birch and pine) contributing up to $85 \%$ to the pollen assemblages ca. 13.4-12.5 cal. kyr BP. A minor decrease in AP (75\%) and a more pronounced one in pollen concentration occurred during the YD. This opening of the vegetation cover corroborates the higher aeolian detrital input suggested by the sediment geochemistry. However, pollen and plant macrofossils do not suggest either substantial deforestation or spread of tundra. This corroborates recent dendrochronological records from Brandenburg and suggests relatively warm YD summers that allowed much broader than initially believed spread of cold-tolerant and drought-resistant boreal trees, such as pines. The relatively low AP values persisted until ca. 10.6 cal. kyr BP, i.e. the early Holocene, when the climate improved significantly and promoted major spread of hazel in the regional forests. The postglacial hunter-gatherer occupation in Brandenburg is archaeologically confirmed since ca. 13 cal. kyr BP, i.e. much later than in the western part of Germany and ca. 1000 years after the major amelioration observed in the Rüdersdorf environmental record.

\section{ACKNOWLEDGEMENTS}

We are particularly thankful to Geologist Jördis Hofmann from the Museumspark Rüdersdorf for her great help in organizing sampling, getting all necessary permissions and spending several Sundays at the outcrop with us. Richard Henneberg, Pascal Olschewski and Ennie Schulz (all FU Berlin) are acknowledged for their assistance in the fieldwork and PD Dr. Ralf Milke (FU Berlin) for his help in identification of the LST.

This work contributes to the project «Individual life histories in long-term culture change: Holocene hunter-gatherers in Northern Eurasia» (SSHRC Partnership Grant Number 895-2018-1004). 


\section{REFERENCES}

Behre K.E., Brande A., Küster H. and Rösch M. (1996). Germany. In: B.E. Berglund, H.J.B. Birks, M. Ralska-Jasiewiczowa and H.E. Wright, eds., Palaeoecological Events During the Last 15000 Years: Regional Syntheses of Palaeoecological Studies of Lakes and Mires in Europe. Chichester: John Wiley \& Sons, pp. 507-551.

Beug H.-J. (2004). Leitfaden der Pollenbestimmung: für Mitteleuropa und angrenzende Gebiete. München: Pfeil.

Bönisch E. (2014). Versunkene Welt der Altsteinzeit und Tiefbau über Tage - Einführung zum Archäologie-Report 2011/12. In: F. Schopper, ed., Arbeitsberichte zur Bodendenkmalpflege in Brandenburg Band 27: Ausgrabungen im Niederlausitzer Braunkohlenrevier 2011/2012. Wünsdorf: Brandenburgisches Landesamt für Denkmalpflege und archäologisches Landesmuseum, pp. 7-43.

Bronk Ramsey C. (1995). Radiocarbon calibration and analysis of stratigraphy: the OxCal program. Radiocarbon 37(2), 425-430.

Bronk Ramsey C. (2008). Deposition models for chronological records. Quaternary Science Reviews 27, 42-60.

Bronk Ramsey C. (2009). Dealing with outliers and offsets in radiocarbon dating. Radiocarbon 51 (3), 1023-1045.

Bronk Ramsey C., Albert P.G., Blockley S.P.E., Hardiman M., Housley R.A., Lane C.S., Lee S., Matthews I.P., Smith V.C. and Lowe J.J. (2015). Improved age estimates for key Late Quaternary European tephra horizons in the RESET lattice. Quaternary Science Reviews $118,18-32$.

Cziesla E. (2004). Late Upper Palaeolithic and Mesolithic cultural continuity - or: bone and antler objects from the Havelland. In: T. Terberger and B.V. Eriksen, eds., Hunters in a Changing World. Environment and Archaeology of the Pleistocene-Holocene Transition (ca. 11000-9000 B.C.) in Northern Central Europe. Rahden, Westfalen: Marie Leidorf Publisher, pp. 165-182.

Dean W.E. (1999). The carbon cycle and biogeochemical dynamics in lake sediments. Journal of Paleolimnology 21, 375-393.

de Klerk P. (2002). Changing vegetation patterns in the Endinger Bruch area (Vorpommern, NE Germany) during the Weichselian Lateglacial and Early Holocene. Review of Palaeobotany and Palynology 119, 275-309.

Demske D., Tarasov P.E., Nakagawa T. and Suigetsu 2006 Project Members (2013). Atlas of pollen, spores and further non-pollen palynomorphs recorded in the glacial-interglacial late Quaternary sediments of Lake Suigetsu, central Japan. Quaternary International 290291, 164-238.

DIN EN (2001). DIN EN 13346, April 2001. Charakterisierung von Schlämmen - Bestimmung von Spurenelementen und Phosphor - Extraktionsverfahren mit Königswasser; Deutsche Fassung EN 13346: 2000. Berlin: Beuth Verlag.

Gehlen B. (2009). A microlith sequence from Friesack 4, Brandenburg, and the Mesolithic in Germany. In: P. Crombé, M. Van Strydonck, J. Sergant, M. Boudin and M. Bats, eds., Chronology and Evolution within the Mesolithic of North-West Europe. Proceedings of an International Meeting, Brussels, May 30th-June 1st 2007. Cambridge: Cambridge Scholars Publishing, pp. 363-393. 
Gramsch B. (2000). Friesack: Letzte Jäger und Sammler in Brandenburg. Jahrbuch RGZM 47, 51-96.

Gramsch B., Beran J., Hanik S. and Sommer R.S. (2013). A Palaeolithic fishhook made of ivory and the earliest fishhook tradition in Europe. Journal of Archaeological Science 40, 2458-2463.

Grimm E.C. (2011). Tilia 1.7.16 Software. Springfield, IL: Illinois State Museum, Research and Collection Center.

Hardt J. and Böse M. (2018). The timing of the Weichselian Pomeranian ice marginal position south of the Baltic Sea: A critical review of morphological and geochronological results. Quaternary International 478, 51-58.

IPCC 2014: Climate Change (2014). Synthesis Report. Contribution of Working Groups I, II and III to the Fifth Assessment Report of the Intergovernmental Panel on Climate Change (Core Writing Team, R. K. Pachauri \& L. A. Meyer (eds.)). Geneva: IPCC.

Kossler A. (2010). Faunen und Floren der limnisch-telmatischen Schichtenfolge des Paddenluchs (Brandenburg, Rüdersdorf) vom ausgehenden weichselhochglazial bis ins Holozän: Aussagen zu Paläomilieu und Klimabedingungen. Berliner paläobiologische Abhandlungen 11, 1-422.

Leipe C., Kobe F., Müller S. (2018) Testing the performance of sodium polytungstate and lithium heteropolytungstate as non-toxic dense media for pollen extraction from lake and peat sediment samples. Quaternary International, published online, https://doi. org/10.1016/j.quaint.2018.01.029.

Litt T., Behre K.-E., Meyer K.-D., Stephan H.-J. and Wansa S. (2007). Stratigraphische Begriffe für das Quartär des norddeutschen Vereisungsgebietes. Eiszeitalter und Gegenwart 56 $(1-2), 7-65$.

Litt T., Schölzel C., Kühl N. and Brauer A. (2009). Vegetation and climate history in the Westeifel Volcanic Field (Germany) during the past 11000 years based on annually laminated lacustrine maar sediments. Boreas 38, 679-690.

Long T., Hunt C.O. and Taylor D. (2016). Radiocarbon anomalies suggest late onset of agricultural intensification in the catchment of the southern part of the Yangtze Delta, China. Catena 147, 586-594.

Namiotko T., Danielopol D.L., von Grafenstein U., Lauterbach S., Brauer A., Andersen N., Hüls M., Milecka K., Baltanás A., Geiger W. and DecLakes Participants (2015). Palaeoecology of Late Glacial and Holocene profundal Ostracoda of pre-Alpine lake Mondsee (Austria) - A base for further (palaeo-) biological research. Palaeogeography, Palaeoclimatology, Palaeoecology 419, 23-36.

Oppenheimer C. (2011). Eruptions that shook the world. Cambridge: Cambridge University Press.

Prentice I.C., Guiot J., Huntley B., Jolly D. and Cheddadi R. (1996). Reconstructing biomes from palaeoecological data: a general method and its application to European pollen data at 0 and $6 \mathrm{ka}$. Climate Dynamics 12, 185-194.

Reimer P.J., Bard E., Bayliss A., Beck J.W., Blackwell P.G., Bronk Ramsey C., Buck C.E., Cheng H., Edwards R.L., Friedrich M., Grootes P.M., Guilderson T.P., Haflidason H., Hajdas I., Hatté C., Heaton T.J., Hoffmann D.L., Hogg A.G., Hughen K.A., Kaiser K.F., Kromer B., Manning S.W., Niu M., Reimer R.W., Richards D.A., Scott E.M., Southon J.R., Staff R.A., Turney C.S.M. and van der Plicht J. (2013). IntCal13 and MARINE13 radiocarbon age calibration curves 0-50,000 years cal BP. Radiocarbon 55, 1869-1887. 
Renssen H. and Isarin R.F.B. (1997). Surface temperature in NW Europe during the Younger Dryas: AGCM simulation compared with temperature reconstructions. Climate Dynamics $14,33-44$.

Riede F. (2008). The Laacher See-eruption (12,920 BP) and material culture change at the end of the Allerød in Northern Europe. Journal of Archaeological Science 35, 591-599.

Schenk F., Väliranta M., Muschitiello F., Tarasov L., Heikkilä M., Björck S., Brandefelt J., Johansson A., Näslund J.-O. and Wohlfarth B. (2018). Warm summers during the Younger Dryas cold reversal. Nature Communications 9, doi:10.1038/s41467-018-04071-5.

Schlolaut G., Brauer A., Nakagawa T., Lamb H.F., Tyler J.T., Staff R.A., Marshall M.H., Bronk Ramsey C., Bryant C.L. and Tarasov P.E. (2017). Evidence for a bi-partition of the Younger Dryas Stadial in East Asia associated with inversed climate characteristics compared to Europe. Scientific Reports 7, doi:10.1038/srep44983.

Schmincke H.-U., Park C. and Harms E. (1999). Evolution and environmental impacts of the eruption of Laacher See Volcano (Germany) 12,900 a BP. Quaternary International 61, $61-72$.

Schroeder J.H. (2015). Rüdersdorf bei Berlin - der Kalkstein-Tagebau: Geo-Glanzpunkt in Brandenburg: ein Blick in die Erdgeschichte - etwa 245 Millionen Jahre zurück. Berlin: Selbstverlag Geowissenschaftler in Berlin und Brandenburg e.V.

Sirocko F. (2009). Wetter, Klima, Menschheitsentwicklung: Von der Eiszeit bis ins 21. Jahrhundert. Stuttgart: Konrad Theiss Verlag.

Stebich M., Mingram J., Han J. and Liu J. (2009). Late Pleistocene spread of (cool-)temperate forests in Northeast China and climate changes synchronous with the North Atlantic region. Global and Planetary Change 65, 56-70.

Stebich M., Rehfeld K., Schlütz F., Tarasov P.E., Liu J. and Mingram J. (2015). Holocene vegetation and climate dynamics of NE China based on the pollen record from Sihailongwan Maar Lake. Quaternary Science Reviews 124, 275-289.

Stockmarr J. (1971). Tablets with spores used in absolute pollen analysis. Pollen et Spores $13,614-621$.

Tarasov P.E., Savelieva L.A., Long T. and Leipe C. (2018). Postglacial vegetation and climate history and traces of early human impact and agriculture in the present-day cool mixed forest zone of European Russia. Quaternary International, published online. https://doi. org/10.1016/j.quaint.2018.02.029.

van Geel B. (1978). A palaeoecological study of Holocene peat bog sections in Germany and the Netherlands, based on the analysis of pollen, spores and macro- and microscopic remains of fungi, algae, cormophytes and animals. Review of Palaeobotany and Palynology $25,1-120$.

Vogel S., Märker M., Rellini I., Hoelzmann P., Wulf S., Robinson M., Steinhübel L., Di Maio G., Imperatore C., Kastenmeier P., Liebmann L., Esposito D. and Seiler F. (2016). From a stratigraphic sequence to a landscape evolution model - Late Pleistocene and Holocene volcanism, soil formation and land use in the shade of Mount Vesuvius (Italy). Quaternary International 394, 155-179.

Werner K., Tarasov P.E., Andreev A.A., Müller S., Kienast F., Zech M., Zech W. and Diekmann B. (2010). A 12.5-ka history of vegetation dynamics and mire development with evidence of the Younger Dryas larch presence in the Verkhoyansk Mountains, East Siberia, Russia. Boreas 39, 56-68. 
Wohlfarth B., Lacourse T., Bennike O., Subetto D., Tarasov P., Demidov I., Filimonova L. and Sapelko T. (2007). Climatic and environmental changes in northwestern Russia between 15,000 and 8000 cal yr BP: a review. Quaternary Science Reviews 26, 1871-1883.

Received on September $19^{\text {th }}, 2018$

Accepted on November $15^{\text {th }}, 2018$ 